\title{
Lessons from Generational Accounting in Japan
}

\author{
By Noriyuki Takayama And Yukinobu Kitamura*
}

Many economists today agree with the usefulness of generational accounting as a powerful alternative to conventional measures of budget deficits. Japan provides the primary example of showing a huge discrepancy between one of the lowest ratios of net debt to GDP and the highest imbalance of generational accounts. The complete lack of a consistent relationship between a nation's deficit or debt positions and the its generational imbalance is not surprising, given that there is no intrinsic connection between the two measures.

Some may argue that Japan's ratio of gross debt to GDP has already reached an alarmingly high level, second only to Italy among OECD countries. The gap between the gross debt and the net debt is mainly explained by the accumulation of surpluses in the socialsecurity system. As social-security funds are held to fulfill the government's pledge to pay future pensions, the Japanese government can less afford to keep spending its way out of the current economic crisis. Generational accounting, in fact, sheds light on the large unfunded portion of future pension liabilities. In other words, the future liabilities (i.e., off balance sheet) of the government can be captured by this innovative accounting method.

There are some reasons for the worsening of Japan's fiscal position. First, growth in tax revenue has remained very low as the economy itself has grown very slowly in recent years. Second, the population is aging at an

\footnotetext{
* Takayama: Institute of Economic Research, Hitotsubashi University, Naka 2-1, Kunitachi, Tokyo, 1868603, Japan; Kitamura: Faculty of Business and Commerce, Keio University, Mita 2-15-45, Minato-ku, Tokyo, 108-8345, Japan. We are grateful to Hiroshi Yoshida for allowing us to use the main results of our collaborate work (Takayama et al., 1999). We are also grateful for the financial support we received from the Bank of Japan. We thank Larry Kotlikoff, Alan Auerbach, Jan Walliser, and Jagadeesh Gokhale for helpful comments.
}

accelerated pace. Third, expenditures on institutional arrangements, such as the socialsecurity system, have been increasing. Fourth, because of the extraordinary fiscal policy packages implemented during 1992-1999 to stimulate the economy amid the deep recession, the government's debt has increased by some 300 trillion yen in eight years.

At the moment, one of the most serious policy issues in Japan is to find a way out of the economic crisis in the short run, while recovering sound fiscal position in the long run, given the prospects of low economic growth and the rapid aging of society. We will show how generational accounting can provide meaningful guidance for addressing this difficult problem.

\section{The Main Findings}

Table 1 presents the basic results of generational accounting in Japan (using 1995 as the base year). They are divided into two cases: case $\mathrm{A}$, in which educational expenditures are treated as consumption; and case $\mathrm{B}$, in which they are treated as transfers. This distinction accounts for some differences for generations between ages 0 and 24 . The percentage imbalance between newborn and future generations is 169 percent for case $\mathrm{A}$ and 338 percent for case B, which implies that future generations must pay about 2.7 times as much tax (net basis) as newborn generations for case A and about 4.4 times as much for case B. This is a huge difference.

Given the same fiscal policy, the generational imbalance is very sensitive to real income growth and discount-rate assumptions. According to demographic projections, the aging process will reach a peak in 2050, after which society will get younger. The fiscal position is also expected to ease after 2050. The higher real income growth rate will reduce the burden of future generations because of a bigger improvement in fiscal position after 2050. On the other hand, the higher discount rate 
Table 1-Generational Accounting: The Base Case (Thousands OF U.S. Dollars)

\begin{tabular}{ccc}
\hline \hline $\begin{array}{c}\text { Generation's age } \\
\text { in 1995 }\end{array}$ & $\begin{array}{c}\text { Case A: } \\
\text { Education as } \\
\text { consumption }\end{array}$ & $\begin{array}{c}\text { Case B: } \\
\text { Education as } \\
\text { transfers }\end{array}$ \\
\hline 0 & 143.4 & 73.0 \\
5 & 169.3 & 90.9 \\
10 & 200.1 & 135.4 \\
15 & 235.9 & 187.4 \\
20 & 278.1 & 257.4 \\
25 & 295.2 & 295.2 \\
30 & 297.8 & 297.8 \\
35 & 287.4 & 287.4 \\
40 & 263.8 & 263.8 \\
45 & 227.7 & 227.7 \\
50 & 173.1 & 173.1 \\
55 & 99.0 & 99.0 \\
60 & 11.9 & 11.9 \\
65 & -47.7 & -47.7 \\
70 & -44.8 & -44.8 \\
75 & -36.0 & -36.0 \\
80 & -26.7 & -26.7 \\
85 & -18.2 & -18.2 \\
90 & -9.7 & -9.7 \\
& 386.2 & 319.4 \\
\hline Future generations & & \\
\hline Generational imbalance & 169.3 & 337.8 \\
(percent): & & \\
\hline
\end{tabular}

Notes: Case A treats educational expenditures as consumption; case B treats educational expenditures as transfers. The exchange rate is assumed to be 93.37 yen per U.S. dollar (1995 average); real income growth is assumed to be 1.5 percent; and the discount rate is assumed to be 5 percent.

will increase the burden of future generations because the fiscal position will be heavily discounted.

If we are only concerned with the net present values of payments after 1995, Table 1 indicates that they are positive for individuals aged 64 or younger and negative for individuals aged 65 or older. This is partly due to the fact that tax payments and social-security contributions that old generations made when they were young are ignored in this calculation, and also partly due to large intergenerational transfers from young to old generations via fiscal policy. If redistribution policy is biased toward old generations, the fiscal burden of future generations will increase as the aging process advances.

Table 2 decomposes the generational imbalance into two factors: demographic change
TABle 2-DeCOMPOSITION OF GENERATIONAL IMBALANCE (PERCENT)

\begin{tabular}{lccc}
\hline \hline Case & $\begin{array}{c}\text { Base } \\
\text { case }\end{array}$ & $\begin{array}{c}\text { No demographic } \\
\text { change }\end{array}$ & $\begin{array}{c}\text { Zero } \\
\text { debt }\end{array}$ \\
\hline A & 169.3 & 42.19 & 154.50 \\
B & 337.8 & 77.21 & 308.64 \\
\hline
\end{tabular}

Notes: Case A treats educational expenditures as consumption; case B treats educational expenditures as transfers. Real income growth is assumed to be 1.5 percent; the discount rate is assumed to be 5 percent.

and fiscal debt position. Even if we assume no debt outstanding (zero debt) in 1995, there remain generational imbalances of 155 percent for case A and 309 percent for case B. Hence, current debt outstanding per se is not the main reason for the generational imbalance. On the other hand, if we assume no demographic change after 1995, the generational imbalance is substantially reduced to 42 percent for case A and 77 percent for case B. This implies that Japan's generational imbalance is largely due to the aging of the demographic structure and intergenerational transfers via fiscal policy.

\section{Policy Options}

The next step is to examine policy alternatives in terms of achieving absolute generational balance between present and future generations. We call this policy criterion the Kotlikoff criterion.

We will conduct six different policy simulations: (i) an immediate and permanent cut in government purchases, (ii) an immediate and permanent increase in all tax revenues, (iii) an immediate increase in income tax revenues, (iv) an immediate and permanent cut in transfer payments, (v) an immediate and permanent cut in both purchases and transfers, and (vi) an immediate and permanent 50-percent cut in all taxes and a reduction in both purchases and transfers. ${ }^{1}$

First, policy (i) implies that government purchases and fixed capital investment must be cut by about 26-30 percent to achieve

\footnotetext{
${ }^{1}$ For more detailed policy analyses, see Takayama et al. (1999).
} 
generational balance. As the ratio between private and public demand with respect to gross domestic expenditures is about $4: 1$, an immediate cut in government purchases of 26-30 percent implies a reduction in gross domestic expenditure of 5-6 percent, which would have a big macroeconomic impact.

Policy (ii) means an approximate 16-percent increase in tax payments. Tax payments and social-security contributions as a percentage of national income in 1995 were 36.8 percent. If scenario (ii) is selected, the gross public burden ratio will jump to 41 percent.

Policy (iii) implies a 54-percent increase in income tax. Compared with policy (ii), it is rather high. Given the percentage share of income tax in total government tax revenue (35.5 percent in 1995), simple arithmetic implies that policy (iii) requires three times as much of an increase as policy (ii). Policy (iii) mostly affects current working generations.

Policy (iv) requires a 25-29-percent cut in transfer payments. The ratio of social-security transfers to national income was 17.5 percent in 1995. A slightly less than 30-percent cut in transfer payments implies a 5-percent decrease in the national income ratio.

We consider two additional scenarios, which seek "small government." Policy (v) is concerned with an immediate cut in both purchases and transfers to achieve generational balance. Here, a 13.6-percent cut in gross government expenditures is needed. This scenario seems to be more acceptable than the other policy alternatives.

Finally, policy (vi) is an immediate 50percent cut in all taxes and a reduction in both purchases and transfers. Gross government expenditures must be cut by 57.4 percent. This implies that the size of government in terms of expenditure shrinks to one-quarter of the current level.

In contrast with the Kotlikoff criterion, we propose an alternative criterion to measure the fairness of intergenerational transfers. We call this concept the Musgrave criterion because Richard Musgrave (1981) formulated this alternative concept. Musgrave himself calls this concept the fixed relative position.

This means that government transfers to the "old" generation as a percentage of the “'young", generation's disposable income is fixed (defined here as $k$ ). This resembles the concept of net income indexation in the case of public-pension transfers. ${ }^{2}$ In other words, it includes interaction with other generations within society, while the concept of net present value of payments for each generation as discussed in generational accounting is an individualistic one, meaning that it is a closed accounting system within a generation. Fixed relative position is suitable for the current social-security system, which is virtually a pay-as-you-go system.

The lifetime relative position $(k)$ in 1995 is calculated to be 0.699 . Suppose the policy stance in 1995 is maintained in the future; then the lifetime relative position will be 0.88 when the aging process approaches its peak in 2045 .

We have conducted two additional policy simulations: (vii) an increase in taxes and reduction in transfer benefits to achieve a balanced budget every year from now on, and (viii) a reduction in transfer benefits and an increase in taxes in order to maintain the level of the fixed lifetime relative position in 1995 $(k=0.699)$. The results show that a balanced budget will be achieved and that the fixed lifetime relative position will be kept constant if transfer benefits are reduced 9-13 percent and taxes are increased by $10-15$ percent. These policy simulation results appear to be more politically acceptable as they satisfy the political trade-off between some transfer benefit reductions (i.e., cutting the size of the government) and some tax increases (i.e., sustaining decent economic policy in an aging society). To put it differently, if the fixed lifetime relative position is kept constant at $k=0.699$, the generational imbalance would be less than 13 percent for case A and 73 percent for case B, even at the peak of the aging process. ${ }^{3}$

\footnotetext{
${ }^{2}$ Net income indexation is a concept in which pension benefits are a given fraction of the disposable income of pension contributors, the working generation. This concept has been adopted in Germany and Japan. For more details, see Takayama (1998).

${ }^{3}$ Nevertheless, some problems remain. First, it is difficult to determine the base-year value of $k$, the fixed lifetime relative position. Second, it may not be politically feasible to change policies such as the level of transfer payments, given an arbitrary value of $k$.
} 


\section{Specific Problems in Japan}

The concept of generational accounting provides a very useful framework for measuring a nation's fiscal position. Its fundamental message is quite clear in that who pays the government's bills is a zero-sum game. The less those living now pay, the more their descendants will pay. Delay not only worsens the situation, but also leaves society uncertain about the future fiscal-policy stance.

However, when we examine the issues of country-specific generational policies such as public-pension reform and national healthinsurance schemes, each country's policy options are limited by economic and political conditions, especially by the status quo.

Martin Feldstein (1976 p. 77) argues that "discussion of optimal taxation implicitly assumes that the tax laws are being written de novo on 'a clean sheet of paper' ,' and that "optimal tax reform must take as its starting point the existing tax system and the fact that actual changes are slow and piecemeal.' We believe that the same logic must apply to generational policy in general and to publicpension reform in particular.

What are the fundamental socioeconomic environments that are relevant to generational policies in Japan? First, prospects of low economic growth and the rapid aging of society with a sharp population decline are unavoidable. Second, the level of public-pension provisions, which are mainly financed on a pay-as-you-go basis, is very generous by international standards and by comparison to the disposable income of working generations. Third, the household saving rate is still very high (see Takatoshi Ito and Kitamura, 1994; Takayama and Kitamura, 1994). Fourth, household intergenerational transfers through inter vivos gifts and bequests are substantial and cannot be ignored (see Takayama and Kitamura, 1994). A sense of family values still prevails in Japan. Fifth, the share of government investment in total gross domestic fixedcapital formation has been much higher than in other OECD economies. In addition, a portion of present government expenditures is used to accumulate public capital that will benefit future generations without repayment. Sixth, financial-market liberalization is just being undertaken. Thus many financial operations still lag behind the U.S. counterpart. For example, the private pension or annuity market is not yet fully developed. A widely accessible, defined-contribution pension scheme similar to $401(\mathrm{k})$ plans in the United States, with proper regulatory institutions to counter investment risks, has yet to be created.

One of this paper's main findings is that, if present fiscal policy continues into the future, then future generations will have to bear intolerably large fiscal burdens over their lifetimes. With the rapid aging of society, we believe that there is a broad consensus for prompt action in fiscal-policy reform, especially reform of the public-pension system. However, the problem is how to reform the public-pension system.

The recent social-security debate around the world mainly concerns three broad issues: (i) whether a pay-as-you-go system or a fully funded system is better (see World Bank, 1994; R. Beattie and W. McGillivray, 1995; Peter Diamond, 1996, 1997; Feldstein 1996, 1998); (ii) whether the system should remain public or be privatized (see Feldstein, 1996, 1998; Robert Eisner, 1998); and (iii) whether the system should use a defined benefit plan or a defined contribution plan.

As each proposal has advantages and disadvantages, a mixed system is advisable for Japan. Overly generous public-pension benefits should be further reduced; the contribution rate could be frozen at the current level or reduced through a partial shift of funding to a consumption-based tax. At the same time, we should encourage private initiatives including private, personal saving accounts for retirement, through the use of powerful tax incentives (see Takayama, 1998).

\section{REFERENCES}

Beattie, R. and McGillivray, W. “'A Risky Strategy: Reflections on the World Bank Report Averting Old Age Crisis.', International Social Security Review, 1995, 48(3/4), pp. $5-22$.

Diamond, Peter A. "Proposals to Restructure Social Security.' Journal of Economic Perspectives, Summer 1996, 10(3), pp. 67-88. 
. "Macroeconomic Aspects of Social Security Reform.' Brooking Papers on Economic Activity, 1997, (2), pp. 1-87.

Eisner, Robert. Social Security: More not less. New York: Century Foundation, 1998.

Feldstein, Martin. 'On the Theory of Tax Reform.' Journal of Public Economics, JulyAugust 1976, 6(1-2), pp. 77-104.

. "The Missing Piece in Policy Analysis: Social Security Reform.' American Economic Review, May 1996 (Papers and Proceedings), 86(2), pp. 1-14.

ed. Privatizing social security. Chicago: University of Chicago Press, 1998.

Ito, Takatoshi and Kitamura, Yukinobu. "Public Policies and Household Saving in Japan" in James M. Poterba, ed., Public policies and household saving. Chicago: University of Chicago Press, 1994, pp. 133-60.

Musgrave, Richard. " Reappraisal of Financing Social Security,' in F. Skidmore, ed., So- cial security financing. Cambridge, MA: MIT Press, 1981, pp. 89-127.

Takayama, Noriyuki. The morning after in Japan: Its declining population, too generous pensions and a weakened economy. Tokyo: Maruzen, 1998.

Takayama, Noriyuki and Kitamura, Yukinobu. 'Household Saving Behavior in Japan,' ' in James M. Poterba, ed., International comparisons of household saving. Chicago: University of Chicago Press, 1994, pp. 12567.

Takayama, Noriyuki; Kitamura, Yukinobu and Yoshida, Hiroshi. ' "Generational Accounting in Japan,' ' in Alan J. Auerbach, Laurence J. Kotlikoff, and Willi Leibfritz, eds., Generational accounting around the world. Chicago: University of Chicago Press, 1999, pp. 447-69.

World Bank. Averting the old age crisis. New York: Oxford University Press, 1994. 